This item was submitted to Loughborough's Research Repository by the author.

Items in Figshare are protected by copyright, with all rights reserved, unless otherwise indicated.

\title{
Like to an anatomy before us': Deborah Huish's spiritual experiences and the attempt to establish the fifth monarchy
}

PLEASE CITE THE PUBLISHED VERSION

http://dx.doi.org/10.1080/0268117X.2011.10555658

PUBLISHER

Routledge (@ Taylor \& Francis)

VERSION

AM (Accepted Manuscript)

LICENCE

CC BY-NC-ND 4.0

\section{REPOSITORY RECORD}

Adcock, Rachel C.. 2019. "Like to an Anatomy Before Us': Deborah Huish's Spiritual Experiences and the Attempt to Establish the Fifth Monarchy". figshare. https://hdl.handle.net/2134/14915. 
This item was submitted to Loughborough's Institutional Repository (https://dspace.lboro.ac.uk/) by the author and is made available under the following Creative Commons Licence conditions.

\section{creative
commons}

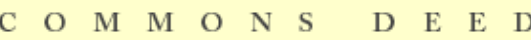

Attribution-NonCommercial-NoDerivs 2.5

You are free:

- to copy, distribute, display, and perform the work

Under the following conditions:

Attribution. You must attribute the work in the manner specified b the author or licensor.

Noncommercial. You may not use this work for commercial purposes.

No Derivative Works. You may not alter, transform, or build upon this work.

- For any reuse or distribution, you must make clear to others the license terms of this work.

- Any of these conditions can be waived if you get permission from the copyright holder.

Your fair use and other rights are in no way affected by the above.

This is a human-readable summary of the Leqal Code (the full license).

\section{Disclaimer 만}

For the full text of this licence, please go to: http://creativecommons.org/licenses/by-nc-nd/2.5/ 


\section{'Like to an anatomy before us': Deborah Huish's spiritual experiences and the attempt to establish the Fifth Monarchy}

And indeed, the whole is an Epistle that may be seen and read by all discerning Christians, to have been written on her heart, by the Spirit of the living God; which I hope will more commend it to every gracious soul, then anything from man can do. ${ }^{1}$

Textual 'anatomies' were published frequently in the late sixteenth and seventeenth centuries. A reader would have expected an attempt by the author to present a detailed analysis of his or her chosen subject, dividing it into parts for closer examination. Like the sense of the word 'anatomy' referring to 'the artificial separation of the different parts of a human body' in order to discover the mysteries of its insides, a textual anatomy delved deeply into obscure areas for the benefit of its readers. The subject under discussion became an organic body, to be explored and analysed in public, imitating the public dissections occurring in anatomy theatres of the period. ${ }^{2}$ Jonathan Sawday notes that 'by the 1650s, it has been calculated, an average of eighteen anatomical texts were being published in England each year, a threefold increase when compared with the situation in the period before the civil war' ${ }^{3}$ Readers, and theatre observers, were eager to learn more about their interiors, and it is not surprising that the word 'anatomy' came to be applied to anything that sought to lay knowledge open to a wider audience or readership.

As textual 'anatomies' could dissect bodies, it was a logical step that they would also look at spiritual matters, examining the inward 'hearts' of men and women. If divine order could be observed in the construction of the human body, it could also be seen in the examining of the work of God on men's hearts by their spiritual experiences. ${ }^{4}$ Separatist and Baptist writers encouraged believers to look inwardly in order to discover the 'work of God 
on their hearts' in order to examine whether they were one of his elect. Deborah Huish's experiences, recorded by her brother-in-law William Allen as The Captive Taken from the Strong: Or, A True Relation of the Gratious Release of Mistrisse Deborah Huish, published in 1658, present us with an example of this 'heart work' including her forbearance during many trials before believing God would save her. These sufferings stemmed from an intense belief that she was damned to hell, and that God had turned his face from her. This, often painful, introspection was a kind of spiritual ‘dissection’ which believers were encouraged to carry out on themselves, and, just as anatomies might be carried out in public, examples of spiritual self-dissection were published both as examples to others, and as advertisements and vindications of this separatist practice. The preface to Huish's conversion narrative, written by her brother-in-law John Vernon, a prominent Baptist and later Fifth Monarchist, likens her condition to that of an 'anatomy': her dissected separatist 'heart' is published as an example to others, and to give them strength on their way to conversion. The exploration of her spiritual 'inward man', as in medicine, 'takes place in order that the integrity and health of other bodies can be preserved'. ${ }^{5}$ Huish's narrative is transcribed, not only for her own spiritual 'reckoning up', but for the benefit of others in her prospective Baptist congregation at Loughwood, in the parish of Dalwood, East Devon, and further afield to the 'saints' in Ireland. As Neil Keeble has written in The Literary Culture of Nonconformity, such writing, because of its allusiveness, 'sets up trains of thought which reach out beyond the individual to all time and space. In that sense, nonconformist style is expansive: it begins in the experience of the individual and comes to encompass all experience. ${ }^{96}$ Through her narrative's depiction of suffering and recovery, Huish becomes an example of how to convert, repent, and hence be 'cured' of her sin. The publishers of Huish's text had a more particular idea of what 'cured' her sense that she was damned eternally: adult baptism. The entire narrative is constructed as a build-up to the moment when she is baptised, and this would certainly have 
encouraged readers in similar spiritual distress to do the same. Huish's troubles and the 'cure' of her convincement had been styled by her male prefacers as metaphors for the struggles of the wider population of believers, from her Baptist congregation to the whole of God's people (or 'Zion' as Baptists and other separatists called it). Her microcosmic state reflects the troubles or 'diseases' of the whole 'body' of believers, to which the only effective cure was baptism.

Deborah Huish’s narrative has rarely been discussed from a literary perspective, and then only as a comparison with the young prophetess Sarah Wight. ${ }^{7}$ By responding to this lack of scholarly attention, this article will both consider Huish's experiences as an 'anatomy' of her inward spiritual condition, and also explore how her plight is used as an allegory for the troubles of the people of Zion. Disillusioned by Oliver Cromwell's increasingly monarchical constitution, the text's compilers, William Allen and John Vernon, express a desire to rally the diminishing saints to welcome in the Fifth Monarchy: this, they thought, would replace the singular Cromwellian regime. Both men felt betrayed by Cromwell's behaviour, especially in his setting up of the Protectorate which resembled the tyrannical monarchy they had opposed before and during the civil wars. Allen seems to have felt this disappointment more keenly that his brother-in-law. He was closer to Cromwell, having been a trooper in his regiment of horse, later promoted by Cromwell to the status of 'Captain', and then 'adjutant-general' when he accompanied his friend to Ireland in 1649. ${ }^{8}$ When Allen questioned the Lord Protector's new regime later, in 1654, he was placed under house arrest at the home of his father-in-law and, it seems, was never able to forgive his friend. These feelings of betrayal feed into the men's presentation of Huish's experience, which shows how despair and captivity could be followed by spiritual joy and regeneration: the downfall of Cromwell's rule could potentially bring forth the Fifth Monarchy. Her release from the power of Satan, which coincides with her baptism at the end of her narrative, is presented as the 
ultimate 'cure' to the wounds in both her body and the congregational body of believers of which she and her brothers-in-law were members, whether those wounds were caused by Satan or Cromwell.

The feelings of profound despair expressed in Huish's narrative indicate that she suffered from extreme spiritual or 'Religious' melancholy, a specific branch of the disease, explored extensively by Robert Burton's The Anatomy of Melancholy (1621). In the depths of her despair Huish believed that she had committed the sin against the Holy Ghost, a sin for which, she believed, there was no forgiveness (B5). Her conviction that she was not one of God's chosen elect had caused her to blaspheme and eventually led her thoughts towards attempting suicide. John Vernon was Huish’s guardian when she accompanied him and his brother to spread their Baptist ideas and doctrine in Ireland, and records the difficulties they had coping with her in this melancholy state:

Oh! how have we been terrified together in our assemblings on her behalf, who have seen her sorrow, and disability to speak, unlesse sometimes in such like Language against her soul, and our seeking her Salvation; who was as a very fearful spectacle pining away (even like to an Anatomy) before us: and how many of us, like the Friends of Job, came at first to mourn, and comfort her; but fainted, left off, relinquished her, concluding hopelessly! how hath a whole Church flagged in their Faith herein. (my italics, a3v)

Vernon's use here of the word 'Anatomy' is interesting, as he depicts Huish's emaciated frame 'pining away' for want of sustenance, resembling a skeleton (another meaning of the word 'anatomy'), and as an anatomical body ready for dissection. Earlier in his prefatory epistle, Vernon aligns her spiritual affliction, and belief in damnation, with specific physical 
degradation presented in the scriptures. Describing her wasted body, he writes, 'with David she might have said I may tell all my bones' (a3). ${ }^{9}$ David's words in Psalm 22 prefigure and prophesy Christ's crucifixion, when he asks despairingly in the first verse, 'My God, my God, why have you forsaken me?' cried later by Christ when he is nailed to the cross in Matthew's gospel. What follows in the psalm is an extraordinarily 'bodily' description of someone in the depths of anguish, fearful that God has left them: David feels as if his 'strength is dried up like a potsherd [broken to dust]; and my tongue cleaveth to my jaws; and thou hast brought me into the dust of death' (22:15). Vernon's preface is similarly 'bodily' in its concentration and writes that Huish was unable to speak, in her melancholy state, except in another, perhaps blasphemous, language. She was weak, and, it was feared, near death. In her own narrative Huish justifies her inability to eat by asking 'why should I eat and drink when I am in dayly expectation of being cast into Hell?' (B6). Aligning this experience to those depicted in the psalms, Vernon continues to use the voice of David: 'my heart is smitten and withered like grasse, so that I forget to eat my bread: [...] my bones cleave to my skin [Psalms 102:4, 5]' (a3). The deliberate blurring of agency by Vernon is evidence of the truthfulness of Huish's suffering, and, more importantly, of her recovery. After her conversion, when she is considering the validity of believers' baptism, she finds that these particular 'Scriptures were FOOD AND STRENGTH to my soul' (E2), and again 'these were MEAT TO ME INDEED at that time' (E2v). ${ }^{10}$ These depictions of Huish's suffering and recovery are akin to most other separatist and Baptist conversion narratives in that they depict spiritual and bodily pain and torture as inextricably intertwined. Her physical appearance is used as an outward manifestation of her inward spiritual afflictions: God's love and comfort is the nourishment she needs to survive and without it she becomes a wasted skeleton, reduced to the 'dust of death'. The depth of her sickness makes her recovery more remarkable, and also attempts to prove to her readers that God can visit the sickest, or the 
most spiritually bereft. Her experience is meant as 'an Epistle that may be seen and read by all discerning Christians, to have been written on her heart, by the Spirit of the living God' (A2r-v). The examinations of her heart are all the more visible because she was spiritually wasted, and in need of nourishment and a cure.

That Vernon should compare his sister-in-law's sufferings to those of Christ is significant for presenting a narrative advocating conversion and believers' baptism. By fending off Satan's assaults on Huish, while she was establishing the validity of believers' (or adult) baptism, God is shown to condone and encourage the practice of the Baptist congregation at Loughwood. The preaching brethren of her church, who also wrote a preface to her work, interpret her uncertainty as the 'subtle slights Satan used [...] to hinder her obedience to the Commandments of Christ, and particularly to that of Baptisme; presenting it as a poor low thing' (b8). She, too, seems to recognise the part of Satan in her doubts and writes of 'some fears on my heart, about my being carried on in that duty, which I see to be so contemn'd and despised: but did judge, these were but the tempters suggestions' (E5). She, like many Baptists, compares the ordinance of baptism to the death and resurrection of Christ, dwelling on Romans 6:4-5: 'I ought by my visible obedience to this his Command, to declare my putting him on, and being planted in the likenesse of his death, being buried with him by Baptism into death; and also my being raised with and by him, and the Power of his Resurrection, unto newnesse of life' (F3v-F4). Being immersed under the water is a reenacting of the death of Christ, and emergence from beneath the surface signifies a new birth. As the 1644 Confession of Faith, subscribed by London Baptist William Kiffin and leading colleagues, shows, 'as certainly as the body is buried under water, and riseth againe, so certainly shall the bodies of the Saints be raised by the power of Christ, in the day of the resurrection, to reigne with Christ' ${ }^{11}$ Baptism was a visible 'signe' that the saints were a people set apart. What Huish's narrative does is to anatomize her heart so that all who read it 
would be encouraged to find strength in scripture, throw off Satan, and take the ordinance of Baptism. By 'sprinkl[ing] them with clean water', Huish writes, they will be cleansed 'from all their Idols and Iniquities [...] thou wilt take away the stony heart and give them hearts of Flesh [Ezekiel 11:19]' (D7v). Huish's 'heart' was already made flesh so that God could mould it and write upon it, and it is laid open by her brothers-in-law for all to observe and marvel at.

I 'The wise Virgin-subject of this ensuing Relation': The narrative as a vindication of Baptist doctrine

The way and manner of the dispensing of this Ordinance, the Scripture holds out to be dipping or plunging the whole body under water: it being a signe. ${ }^{12}$

Huish's narrative is certainly a vindication of Baptist ordinances, which it performs by aligning Satan, the tempter, with the critical views of all those who 'despised' and persecuted the adherents of believers' baptism. This was a powerful argument against those who sought to present the Baptist church's doctrines as heretical, and potentially threatening to the fabric of society. Contemporaries were mindful of the rebellious and violent continental Anabaptists who had attempted to establish a theocracy in Münster a century before in the 1530s. This group of millenarians had violently attempted to establish a 'New Jerusalem' and advocated adult baptism, abolished private ownership, and practised polygamy. Seventeenth-century English Baptists were called 'Anabaptists' by their opponents because they shared with their predecessors the practice of believers' baptism, which allowed into their congregations only those old enough to examine their consciences. Anne Dunan-Page identifies five extreme charges that were levelled against the Baptists because of these similarities: 'heresy, political rebellion, murder, sexual licence, and madness'. ${ }^{13}$ Many regarded the Baptist practice of 
'dipping' or completely immersing people in water, in order to baptise them, as a way of indirectly murdering their followers. Dunan-Page refers to Richard Baxter's vindication of infant baptism which shows his concern for partakers, particularly women: 'in Cities like London, and among Gentlewomen that have been tenderly brought up, and ancient people, and shop-keepers, especially women that take but little of the cold ayr, the dipping them in the cold weather, in cold water, in the course of nature, would kill hundreds and thousands of them, either suddenly, or by casting them into some chronicall Disease'. ${ }^{14}$ For Huish, baptism by immersion was the ultimate 'cure' for her ills: not the cause, as opponents of the Baptists, like Baxter, testified. Not only was baptism presented as a danger to women's health, but it was also said to endanger their virtue and disrupt social hierarchies. Thomas Edwards, author of the encyclopaedic Gangraena which sought to 'catalogue and discover' the 'pernicious practices of the sectaries', shows concern at these disruptions. He draws his concerned readers' attentions to 'anabaptists' baptising 'young maids, Citizens daughters, about one and two a clock in the morning, tempting them out of their fathers houses at midnight to be baptized[,] the parents being asleep and knowing nothing'; 'their Husbands and Masters could not keep them in their houses'. ${ }^{15}$ Edwards expresses the fear that the Baptists who lured and enthralled the women to the rivers were trying to repopulate the world with their (illformed) heretical offspring, ignoring the rights of their husbands and fathers. ${ }^{16}$ Edwards was drawing on popular perceptions that 'anabaptists', like their sixteenth-century counterparts, held both possessions and women in common, and, following 2 Timothy 3:6, led 'captive silly women laden with sins, [...] away with divers lusts'. The word 'captive' is significant in that it suggests that the women have been enthralled by their captors, and follow them merely to fulfil their insatiable lusts. Huish's narrative, entitled The Captive Taken from the Strong, uses the same sense of the word, but refers to her being held 'captive' or being 'captivated' 
by Satan. It is God, accompanied by her convincement of baptism (it is clear that she read the scripture for herself), which saves her from Satan's continuing assaults and being in his thrall.

The practice of dipping a believer in a river, in public and supposedly completely naked, further inflamed popular opinion on the Baptists. Daniel Featley’s anti-Baptist tract, The Dippers Dipt, published in 1645 and a sixth time in 1660, was one of the more popular 'heresiographies' which sought to disprove the 'dipping' of believers in order to baptise. He writes 'the resort of great multitudes of men and women together in the evening, [...] going naked into rivers, there to be plunged and Dipt, cannot be done without scandall, especially where the State giveth no allowance to any such practise' ${ }^{17}$ The tract's frontal woodcut, by William Marshall, shows naked men and women immersed in the river, but most prominent are the bare-breasted female Baptists labelled 'Virgins of Sion'. The male baptisers are shown removing the shawl about the women's shoulders in order to push their naked bodies under the water. Featley wrote later that the believers did 'strip themselves stark naked [...]: and when they are questioned for it, they shelter this their shamelesse act, with the proverb Veritas nuda est, the truth is naked, and desires no vail, masque, or guise; which reason if it were good, would hinder them from holding private Conventicles as they do'. ${ }^{18}$ His work, along with Edwards's Gangraena, seems to be an attempt to bring the errors of the sectaries, in his case the Baptists, to public view. Featley criticises the Baptists’ secret meetings, which were thought seditious due to their cloak of secrecy, and his work was to 'lay open' the workings and heresies of the congregations which they held secret. Replying to his own sectarian critics, Edwards wrote that he had not finished with these, his 'antagonists', but would 'more fully anatomize and rip them up, and further justifie and cleer all things excepted against in Gangraena' ${ }^{19}$

As if in reply to allegations of this kind, the Baptist churches in London issued a Confession of Faith, of those Churches which are Commonly (though Falsly) Called 
Anabaptists, published a year earlier than Featley's tract, in 1644. Signed by William Kiffin and Thomas Patient, the Confession vindicates the practices of the London Baptist congregations by taking 'off those aspersions which are frequently both in Pulpit and Print, (although unjustly) cast upon them' (A1). The writers sought to justify their practices with scripture in order to confirm the faith of God's chosen people, but also to defend themselves against accusations of scandal. Article XL outlines the 'way and manner' of dispensing baptism, proven by scripture to be by 'dipping or plunging the whole body under water: it being a signe'. Aware of opinions like Featley's, the congregations appear to have debated how to make this ordinance appear less scandalous, and in the margin, above the scriptural references, is written 'the word Baptize, signifying to dip under the water, yet so as with convenient garments both upon the administrator and subject, with all modestie'. ${ }^{20}$ In a metaphorical extension of this concern, Huish's transcribed text is presented within the 'convenient garments' of prefatory epistles: her words are controlled by her transcriber, Allen and ‘faithfully written from her own mouth’ (A1). She was, effectively, ‘opening herself up’ for the reader to observe 'the law of God written on her heart', which was a requirement of entry to most separatist and Baptist congregations, of which the Loughwood Church was one. ${ }^{21}$ The fourth preface to Huish's narrative was written by two of the 'brethren approved of in the church to exercise their gifts', John Owen, and James Hitt, and one on 'tryall', Thomas Parsons, ${ }^{22}$ who show that even though they 'were very much strangers' to Huish's 'sore bondage, and captivity of Spirit', they listened 'to the advantage of our souls' to her 'wonderful deliverance' (b6v). The Loughwood congregation, gathered in the parish of Dalwood, East Devon, required all prospective members to stand in front of the congregation and explain how they came to be convinced of the workings of God on their hearts. Huish's experience was 'heard out of her own mouth, in the midst of the Congregation' early in 1658, and the brethren suggest that it would have been 'more particular and large' had there been 
more time: 'a near Relation of hers' whom God had used as an 'Instrument of her enlargement' (b7) also agreed for it to be shorter. This 'near relation’ was certainly William Allen (another of the 'brethren approved'), who transcribed Huish's published account, likely to have been an 'enlargement' of the original conversion narrative given in front of the congregation. $^{23}$ The three brethren felt it necessary to include their observations of her speaking: she thought long between sentences in a 'secret, inward silent lifting up of her soul to God in thanks-giving', dwelled on the 'darkest passages of her blaspheming God’ (b7), and was careful to correct herself, or others who had known her, if they 'slipt' and would 'state the matter aright' (b7v). These observations were intended to leave the reader (whether critic or believer) in no doubt of the narrative's truth, or the godly way by which it was delivered.

Deborah Huish’s narrative was certainly published both as a rallying call to existing believers, and as a vindication of her congregation from accusations directed against lascivious and uncontrollable women. Huish is immediately cast as 'the wise Virgin-subject of this ensuing Relation’ (A8v), by John Vernon, referring metaphorically to the parable of the wise and foolish virgins of Matthew 25:1-13, but also literally, perhaps, to her legal status as a 'virgin' ${ }^{24}$ Huish remained unmarried for her twenty-eight years recorded in The Captive, and her surname had not altered when she died three years after its publication. John Vernon reveals that Deborah was the third daughter of James Huish (or Huyshe) of Sand, Sidbury in South Devon (a1). ${ }^{25}$ Several sources agree that she was christened on the 5 September 1628 and was buried on the 21 August 1661, dying at the age of thirty-three. Her two elder sisters, Mary and Anne, had married William Allen and John Vernon respectively, ${ }^{26}$ and her younger sisters all married if they survived infancy. ${ }^{27}$ That Huish was a member of the gentry and unmarried was an antidote to the lascivious sectarian women that contemporaries like Edwards and Featley vilified. That Allen and Vernon had married into James Huish’s family, and that Allen, in particular, had stayed at his residence at Sand suggests that he was not 
averse to his daughters accompanying their army husbands to Ireland, or subsequently joining the Loughwood Baptist congregation. However, neither his nor his wife's name can be seen in the congregation's records, although the names of Deborah Huish, William Allen, and John and Anne Vernon all appear on the list of members. ${ }^{28}$ Making Huish’s parentage clear is, in part, to appease those who, like the disciple Thomas, 'question what their eyes see not, and their fingers feel not' (A8v) unless they are 'informed more perfectly [...] of the truth thereof' (a1). It is also, perhaps, a way of vindicating the congregation, and the Baptists more generally, of wanting to overturn established hierarchies and make all property in common. Huish was not led out of her father's house against his wishes like the 'silly women' portrayed in Edwards's accounts, but wisely considers the validity of adult Baptism before partaking of the ordinance, persuaded only by the word of God. Apart from mentioning her parentage, whatever earthly riches Huish had are ignored. As Bernard Capp writes, in his study of The Fifth Monarchy Men, 'secular aristocracy was as nothing compared to the aristocracy of the elect'. ${ }^{29}$ For the saints, monetary riches were incomparable with spiritual treasures. Her background is mentioned merely to vindicate her, and her congregation's, behaviour: the 'truth' was indeed 'naked', as Huish anatomised her heart for the benefit of all, whether they were non-believers or Baptists.

II 'They did much mischief in the body': Allen, Vernon, and establishing the Fifth Monarchy

Spirit and Voice hath made a league

Against Cromwel and his Crown

The which I am confident the Lord

Will ere long so strike down.

Spirit and Voice hath made a league against him

That hath such a Traytor been, 
And acted such false treachery

Against the mighty King. ${ }^{30}$

Cromwell's dissolution of the Barebones Parliament (or the Parliament of Saints) in December 1653, and the establishing of the Protectorate later that month, caused, as McGregor writes, 'Militant Baptists, particularly the Irish Army officers' to share the 'belief that Cromwell had usurped the role of King Jesus in adopting rule by a single person'. ${ }^{31}$ With the dissolution came intense disappointment. Instead of a godly government of 'saints', the country was again to be ruled by a single person: to many of his previous supporters, Cromwell appeared to have accepted Kingship. He had also supported the imprisonment of several ministers, as the Baptist Association lamented: 'those that have beene glorious lights on the right and left hand, are shutt up in bonds'. ${ }^{32}$ William Allen was placed under house arrest at this time. He had returned from Ireland in 1655 to speak privately to the Protector about the matter of single authority where, according to John Copleston's intelligence to secretary Thurloe he 'did nettle the protector extreamly' and the two parted 'in a huffe'. ${ }^{33}$ On returning to his father-in-law's residence at Sand, Sidbury, he was said to have met with 'divers strangers, particularly from Somerset and about Bristol', riding 'comonly with a kind of vizard over his face, with glasses over his eyes'. Everyone who conversed with him reported 'him to be a person highly dissatisfied with the present government' and Copleston also reported his attendance at a meeting with 'a cavalier of good estate'. Hugh Courtney, an active Fifth Monarchist, was also at this meeting speaking 'treason' and was sure that when he returned to London he would be 'sure to meet hearts and hands enough to carry on the anabaptisticall interest; that his [Cromwell's] government should not stand many months, and that deliverance was at hand' ${ }^{34}$ Allen was 'awoke from sleep in his Father-in-law Mr. Huish's by the entrance of two armed troopers', who kept him there as a precaution by 
Cromwell's order. He wasted no time in sending a reproachful letter to his captor, writing: 'I am ill accommodated having no money nor cloaths for me, my poore wife, nor littl one', and begged to 'goe to hear the word, if it might be'. ${ }^{35}$ He resented his treatment by his former friend Cromwell, which he thought was unjust:

You are also pleased to tax me with having as light an esteeme of you as of C[harles].S[tuart]. though neither any word in my letter nor any action of mine did ever give you ground for such a surmise. What my esteem hath been of you in some verticall forsakeing dayes I beleev you can remember; and I cann truly saye, if I have erred, it hath been, I feare, in esteeming too highly of you. ${ }^{36}$

Unlike Courtney, who was arrested and lodged in Carisbrooke Castle with Major-General Harrison, Allen was soon released with no evidence of 'treason' found against him, and he returned to the army in Ireland. Whatever his opinions of Cromwell were before this exchange, he certainly continued to mourn that the glorious cause of the saints, that he and his friends had envisaged, seemed lost.

Bernard Capp rightly asserts that, 'the Fifth Monarchist movement emerged as a reaction to fading, not rising expectations'. ${ }^{37}$ To coincide with the calling of the first Protectorate Parliament, the London-based Fifth Monarchists published the Declaration of Several of the Churches of Christ and Godly People [...] Concerning the Kingly Interest of Christ, to vindicate their imprisoned champion Christopher Feake, but also to advocate that Christ alone was the ruler of the nation. They wrote:

This subtil spirit and soul of Antichristianism (in a new body) hath bewitched many of the Common sort, and is wonderful cunning to deceive; although by this universal 
falling away amongst us, the Man of Sin is (blessed be Jehovah) more discovered then ever, who must be destroyed with the breath of Christ's mouth, and the brightness of his coming. ${ }^{38}$

Although a new 'body' (parliament) had been set up by the 'Man of Sin' (Cromwell), the Fifth Monarchists thought that their 'antichristian' sins would have been 'more discovered' to Christ at the imminent second coming. ${ }^{39}$ By the first half of 1657 , only a year before Huish's narrative was published, Capp writes, 'a scheme to make Cromwell king was being canvassed', which further incensed the group who held that Christ alone could wear the crown. ${ }^{40}$ 'Universal falling' is a common term, also used by Allen and Vernon, for the falling away of people from their earlier belief in a godly parliament, and becoming 'bewitched' by a new monarchy rather than the one they had cast off. In his preface to Huish's narrative, later in 1658, William Allen mourned that 'some of Zion's pretended lovers raised and lifted up (it's to be feared too highly) by her, are dealing unkindly with her, and that under highest pretences of real affection to the name and cause of God, and interest of his people' (A6). Allen and his fellow millenarians, who saw the overthrow of King Charles as the end of the fourth empire before the establishing of the Fifth Monarchy and the rule of the saints on Earth, saw that Cromwell and his men, whom they had 'raised up' and put faith in, were now treating them with contempt.

Reading Huish's narrative in light of these criticisms of the government reveals that, as well as encouraging 'poor, drooping, disconsolate, discouraged souls' (A4) who were suffering in the belief that they were not one of God's elect, and that Satan's assaults would batter their hearts for eternity, she was also a metaphor for the wider body of 'drooping' believers. Huish's 'raising' from the assaults and temptations of Satan was, according to Allen, a 'signal mercy' to the saints and a 
pledge and pattern of what God will yet do, not onely for poor disconsolate souls in like conditions; but also for the recovery and raising his publicke works, so far gone back in these Nations, in this sad declining day, as causeth many of Zion's Friends to speak sadly and doubtfully of them, as they of Christ. (A5v-A6)

Allen sees the uplifting of Huish as a 'pattern' for what God would do for the people of Zion who have 'so far gone back' in their 'raising' of his 'publicke works'. Her individual struggle is used as a metaphor for the whole of Zion 'in these worse days of declining' (a1). Vernon runs with the metaphor and compares the wider community of Zion to the biblical lands, and asks his readers to remember 'God's special presence with Israel, in driving back Jordan by his mighty power' (a6). Israel's response to this, shown in the book of Joshua, was to erect 'Pillars of praise, to encourage the future Faith and hope of faithful ones that should follow God fully'. The relation of Huish's experience in her published narrative plays the part of one of these 'pillars of praise' to encourage other believers not to cease following God. Her work is both a 'monument' and a 'pillar' of the cause of the saints. Vernon reminds his readers that the Israelites could not possibly have expected God's presence if they had followed their 'humane design, to which they were sometimes subject through unbelief' (a6). Comparing this biblical conflict and resolution with recent events, he illustrates:

Neither in our dayes have any persons ground to suppose (much lesse to conclude) that the Lords eminent presence in the high places of the field, scil. Naasby and other parts with his people, while they faithfully followed him, can now yeeld any incouragement to expect the like presence of God, while they are turning back, and declining from him. (a6r-v) 
Both Allen and Vernon had fought with Sir Thomas Fairfax's army who triumphed at the battle of Naseby on 14 June 1645, the most decisive battle of the first Civil War. The Parliamentary victory restored hope that those fighting against the King were on God's side, and that their faith in a new godly kingdom was being rewarded. If these people of God had ceased worshipping and believing, then they could not expect God to fend off the approaches of the antichrist, whether it was from Jordan, or the Royalist regiments of 1645 . Although Huish herself had 'some sad considerations about falling away, after grace received; which made my soul to tremble in the thoughts of it, to think how dishonourable that would be to the name of God' (E4r-v), she triumphed over Satan's assaults and her experience remained as a 'pillar' (a2) propping up the ‘drooping’ godly community.

After Allen, Vernon, and Huish returned home from Ireland, it is clear that the desire to unite disparate and 'drooping' congregations, despite national boundaries, remained a particular concern. Allen later framed Huish’s narrative as an 'epistle’ (A2) addressed to the churches in Ireland, which suggests that it was intended to encourage a closer union between the churches in the West Country, and those in Ireland. While in Ireland, Huish had visited the meeting houses of the Baptists who met in Dublin, including the house of Thomas Patient. Her narrative, by showing the conquering of Satan, is intent on weakening his corrupting suggestions to other godly members, wherever they may be. Apart from appearing as the bearer of a message to members of John Rogers's congregation worshipping at Christ Church Cathedral, Dublin, where Rogers recorded 'they did much mischief in the body', ${ }^{41}$ Vernon also carried messages between the Baptist churches in Ireland (in Waterford, Dublin, and Kilkenny) addressed to those of the same persuasion in London, the first of which was written on 1 June 1653. Vernon, who was ‘in full communion’ with the Irish churches, was to promote a 'more revived correspondency' by delivering 'letters and loveing epistles' in 
which they had previously 'found great advantage not only by weakning Satan's suggestions and jealousyes, but it hath begott a closer union and knitting upp of heart'. ${ }^{42}$ Exchanging letters and information was intended to unite the churches to enable them to fight Satan (in whatever guise he might appear): a common enemy. The Irish churches mourned:

Oh, how many packetts have passed filled with worldly matters since wee have heard one word from you, or you from us, of the condition, increase, growth and decrease of the commonwealth of Israell [...] who were some yeeres since brought low through oppressions, afflictions and sorrow. [...]. Doth it not appeare by our litle zeale for him, and lesse delight in his wayes, with constant complaynings, with litle sense of our victory over our leanese, our drynese and barrennese. Are not these instead of the songs of Syon [...]. For, doubtless now, if ever, wee are especially called uppon to put on the whole armoure of God that wee may be able to stand in this day, and, having done all, to stand. ${ }^{43}$

In recent times, the churches seem to have neglected to assess the condition of 'the commonwealth of Israel' since recent oppressions: imprisonment, persecution, and slander. As Huish's body had withered and dried itself 'like to an anatomy', the congregations recognise that they themselves are sick and barren as they are; they have no capacity to bring forth joy, or establish the kingdom of heaven on earth. Accompanying the sickness metaphor is a call to the saints to take arms against their persecutors and to the many unbelievers: a rallying call for those who were in the depths of mourning and despair to unite and rise up together. Even as late as 1658, Vernon wrote a similar reproach in his preface to The Captive, addressing the Irish churches: 
And seeing the Lord alone can heal our sicknesse, and our wound; and the breach upon us, which is wide as the Sea; let every true Mourner humbly approach before him, on the behalf of our selves, and whole Zion, [...]; \& on behalf of the afflicted, deserted, unbelieving, divided, and thereby liable to be destroyed people. [...]: for now all men almost see our sicknesse, and our wound; how foolish many Physitians and our false refuges have proved. (b3)

The people of Zion are presented as both literally and metaphorically wounded and divided from each other. The congregations are separated by something 'which is wide as' the Irish Sea, but they are also experiencing a spiritual breach: one that cannot be cured by a physician. Like Huish, members should fight their afflictions and unite against Satan, whatever he might represent. Her text is both a literal and allegorical message for uniting the churches in preparation for the second coming of Christ. Catharine Gray similarly notes the text's propagandistic qualities, writing that it evokes 'a specific community that keeps its

identity intact even as it crosses the borders of kingdom' ${ }^{44}$ I would argue that the text was published to strengthen and further establish Baptist congregations' ties to each other, whose identity was constantly questioned by doubters and persecutors. Vernon writes despairingly that 'all men almost' see the movement's division and uncertainty and Huish's text is both part of an urge to heal the 'wound' that has occurred between the geographically separate Baptist congregations, and also to heal the 'wounds' of individual believers that make up the whole body.

III 'What bare anatomy of griefe is this?' 45 Deborah Huish's Melancholy Experience and the Assaults of Satan

The seed of woman it is that 
That unto man must show

Over Sin and Satan a victory,

And utter overthrow. ${ }^{46}$

While it seemed that William Allen and John Vernon had distanced themselves from violent plots, and the violent uprising organised by Thomas Venner, they still encouraged drooping members of the elect not to lose sight of their battle with the antichrist, whether it be against their own unbelief, or the impositions of the Lord Protector. Metaphors of warfare were used to represent opposition to anything that went against the beliefs of the saints. The Fifth Monarchist Declaration against 'Carnal Plots, Devilish Designes, or Ungodly combinations of men’ clarified that it was ‘those gracious Principles which have (we hope) carried us (and yet do daily) into a spiritual warfare and hot contest for this Cause of Christ' ${ }^{47}$ By the mid1650s many saints were dispirited with Cromwell's treatment and imprisonment of their fellow believers, and saw that he had ignored the establishing of a Fifth Monarchy that would be led by godly men. It is perhaps unsurprising that the Protector came to be aligned with distorted 'devilish designes'. On one of her excursions to Cornwall to visit John Carew who had been imprisoned in Pendennis Castle, Anna Trapnel and her three friends were accosted by an 'honest Trooper' who had been ordered by the Lord Protector to 'disarm Cavaliers'. Trapnel was said to reply: 'Thy Lord Protector we own not; thou art of the Army of the Beast'. ${ }^{48}$ Although this was only reported speech, it is clear that ideas associating Cromwell with the forces of the antichrist were being circulated. Carew, himself, was imprisoned in part for saying that Cromwell had taken 'the Crown from the head of Christ, and put it on his own'. ${ }^{49}$ Trapnel's untitled folio of verse recorded by an amanuensis, quoted above, frequently alludes to the destruction of the Cromwellian regime in favour of the reign of the godly on 
earth. She prophesied that Cromwell would soon be struck down, and that the saints would have victory over both 'Sin and Satan'.

Huish’s text was clearly prefaced and titled with a view to it appearing as an example to others of how to overcome Satan's temptations and afflictions. It seems likely that it was William Allen who titled the narrative The Captive Taken from the Strong to show that his sister-in-law had been released from 'under the Power of the Tempter, by whose firy Conflicts she had been sorely vexed for about fourteen years' (A1). At this time believers were encouraged by their Puritan pastors to see their inner lives as what Michael MacDonald, in his Mystical Bedlam, calls 'moral allegories', and their emotional disturbances (melancholy, grief, and distress) as part of the battle between God and the Devil. ${ }^{50}$ Hannah Allen, writing of similar melancholic feelings in her Satan's Methods and Malice Baffled, records a conversation with her Aunt where she says she has 'great struglings and fightings within me; [...] I am just as if two were fighting within me, but I trust the devil will never be able to overcome me'. ${ }^{51}$ It was as if the believer's body had become a battleground, and Huish’s body was no exception. William Allen's title for her narrative refers to the fortyninth chapter of Isaiah which describes that the 'captives of the mighty shall be taken away, and the prey of the terrible shall be delivered' (Isaiah 49:25). God declares that he will contend with all enemies that contend with his followers, and he promises he will 'save thy children'. Huish is set up as the prisoner of Satan, and God is shown to have fulfilled his promise in saving her from 'the Power of the Tempter'. Many published spiritual narratives like this expressed similar desperation in a loose framework of affliction (whether from literal or metaphorical devils) and deliverance. Potential members of separatist congregations were actively encouraged to interpret their lives in this way and tell their fellow believers of their 'conversion' in order to become one of the congregation, or 'people of Zion'. Owen Watkins, in his seminal study The Puritan Experience, shows that those who wrote such narratives 
were neither preachers nor teachers and mostly lacked the skills of [...] better known men, but so thoroughly and so persistently had Puritan preachers anatomized the soul and the content of the Christian life that any of their followers had the means both to relate behaviour to the inner process of regeneration and to describe what was happening. $^{52}$

No longer did believers need the intervention of a priest or minister to analyse their relationship with God: they had the language and images to analyse and write about it for the benefit of themselves and others. This 'anatomising', 'taking apart', and 'looking into' was important, not just for the individual, but for the rest of the godly who could learn from such experiences. Huish had, in effect, cut herself open so that all others could see the battle going on within her heart.

The metaphorical image of the believer's body laid open for observation is most powerfully illustrated by a later woodcut attributed to Robert White for the first edition of John Bunyan’s Holy War, Made by Shaddai [God] upon Diabolus, For the Regaining of the Metropolis of the World. Or; The Losing and Taking Againe of the Town of Mansoul (1682). Here, a town named 'Mansoul' is surrounded by the army of 'Diabolus', in the shape of a black dragon on the left, and 'Shaddai's army' led by 'Emanuell' (Christ) on the right. The town is overlaid with the figure of a man whose heart is at the centre and labelled 'Heart Castle'. The town of 'Mansoul' is an explicit representation of both the souls of believers and the larger gathered people of Zion. The image is applicable to Huish's situation (she was a prisoner of Satan), but it would have been equally relevant to other believers under temptation and despair. Bunyan states: 
The Town of Mansoul is well known to many,

Nor are her troubles doubted of by any

That are acquainted with those Histories

That Mansoul, and her Wars Anatomize.

Then lend thine ear to what I do relate

Touching the Town of Mansoul and her state,

How she was lost, took captive, made a slave;

And how against him set, that should her save. ${ }^{53}$

Although referring to a time later than Huish would have been familiar with, Bunyan describes how man's soul was, at that time, imprisoned by the forces of Satan. England, the people of Zion, and the individual believer, he thought, were under threat of an arbitrary Catholic government which would make the people 'slaves'. Nearly twenty-five years earlier, Allen and Vernon were similarly disillusioned with Cromwell's government, which, as has been discussed, imprisoned those of the godly both literally and metaphorically. As Gray writes: 'Huish's metaphorical captivity and release at the hands of Satan [is] an allegory for a body of saints held captive literally and figuratively to a blacksliding, tyrannous government and to slanderous "public reproach" (b1v)'. ${ }^{54}$ Because of its allegorical qualities, Huish’s narrative becomes timeless: it was meant to be applicable to all the saints from its publishing until the coming of Christ. The 'Holy War' between God and Satan could be mapped onto the Civil Wars in England, and the conflict in Ireland during the 1650s, but also in the hearts of individual believers, and the conflicts (private, public, or both) that they would face in times to come.

Robert Doyley’s preface to Huish's narrative suggests that her self-condemnation was 'reversed by her Heavenly Father, who hath set her feet in a large place: so that now, if sin, 
Satan, her own corruptions, or any other Spiritual Adversary, comes to lay any thing to her Charge, she may be ready (the Lord assisting) to produce her pardon' (b5). Huish had managed to overcome her self-loathing, and would continue to use 'the weapons the Lord gave her at the first' (A3) to fight against any more assaults from Satan. The word 'corruptions' seems to have been italicised for its biblical origins, rather than its importance; but it is revealing in its suggestion of both bodily and spiritual problems. As well as meaning moral perversion, ‘corruption' can also mean disintegration or decomposition, in an unpleasant sense; it can also refer to the matter inside a boil, or sore, which needs to be expelled from the body in order for it to heal. Both the bodily and spiritual connotations are applicable to Huish's state: as well as being vulnerable to spiritual corruption, Huish experienced intense anxiety, or 'melancholy', which physicians recognised as a bodily illness characterised by an imbalance of humours. Every human body was thought to have four types of 'humours' flowing through it: choler (originating in gall), phlegm (from the liver), sanguine (the blood), and melancholy (from the spleen). Michael MacDonald writes that the dominance of one of these humours in an individual's constitution was assumed to be inevitable, and not in itself a sign of illness: for instance a melancholy complexion 'proceeds from an abundance of the natural form of that humor, rather than its corrupted "adjust” state, and produces a character that is sober, contemplative, and timorous'. ${ }^{55}$ While it was possible to be 'naturally' melancholy, it was the 'corrupted “adjust” state' that seemed, according to Burton, to attract the Devil, who used this 'black humour' as his bath:

[Satan] insults and domineeres in melancholy distempered phantasies and persons especially, Melancholy is balneum diaboli, as Serapio holds, the divells bath, \& invites him to come to it. [...] So that such blasphemous, impious, uncleane thoughts, 
are not his owne, but the Divells; they proceed not from him, but from a crazed phantasie, distempered humours, blacke fumes which offend his braine. ${ }^{56}$

Even Huish's sister Anne recognised, while observing Deborah's 'dejected frame', that the first 'blasphemous thoughts cast into [her] mind' could be dismissed as not hers, 'but the Devil's' (B1v). Such was familiarity of the Devil's suggestions in this period, that this eased Huish for a time, but she continued to be 'assaulted' by him until 'the Lord of his free Mercy began to make way for [her] escape' (B1v-B2). The narrative is constructed out of several of the Devil's 'assaults', and, at times, she writes that she believed that she had talked with him and was 'possessed' (B2). Her belief that she was one of the Devil's party continued throughout her stay in Ireland, where, while staying with a friend at her congregation's meeting-house, she heard 'a great voice' (B7v) above her, which she thought to be the devil, until 'Mistress Roe' told her it was the 'people who lay over [her] head'. Before morning she heard 'a ratling of Chains' which she 'judged to be the Devils hasting to fetch me away' until Roe told her that it was 'onely people opening Shop-windows' (B8). Huish remained unsatisfied and lingered 'in an inexpressible horrour'. Throughout the narrative the cycle continues: Huish’s humoral corruptions both aggravate, and are aggravated by, her belief in her own sinful estate, and the Devil’s own 'blacke fumes'. Doyley recognises the difficulty of her cure when he lists four different adversaries (sin, Satan, her corruptions, and any spiritual adversary), whose assaults work to the advantage of the others.

By laying open her heart, Huish was allowing others to see the struggles between God and Satan at first hand, and learn how to overcome them. For the treatment of melancholy, Burton recommended: 'counsell, good comfort is to be applyed [...] by hearing, reading of Scriptures, good Divines, good advice and conference, [and] applying God's word to their distressed Souls'. ${ }^{57}$ By reading Huish's narrative, believers would be comforted, not only by 
the scriptures she lists at the end of the work, but by the hope that Satan could be overcome, no matter how terrible his assaults. She was saved from feelings that made her want 'to cast my self down out of a window to kill my self' (B5), and conquered her enemy. ${ }^{58}$

\section{IV 'A glorious work as this, out of such a barren womb of apprehended impossibilities'}

[Anatomy] is not the local anatomy of a man and dead corpses, but the essential and elemental anatomy of the world[,] and [it is] man that discovereth the disease and cure. $^{59}$

It is clear that Deborah Huish's text was recorded and published to soothe the disheartened and disillusioned saints, both in England and Ireland, that had been let down by Cromwell and his Protectorate. The rule of the saints was lost, or at least far away. Huish's narrative, and the experience she presents of her rescue out of the arms of Satan, is called by Allen ' $a$ glorious work' (A5v) undertaken by God and herself. Allen conceived the task of freeing Huish from the Devil's captivity was impossible, as was, it seemed, the freeing of the people of God from out of the tyranny of the Protectorate. They were both 'apprehended impossibilities': the saints' hopes were stuck in a barren womb where nothing could grow, flourish, or be conceived. It was God that freed Huish from her captivity which enabled her to fight against Satan and give birth to joy, the good news of her conversion. This gave hope that anything was possible for the saints, if God was behind them, even if 'Faith, hopes, and hearts, of the strongest failed concerning it' (A5v).

Despite the hope the narrative and its accompanying epistles expressed, the disillusionment with the Protectorate and its oppression of religious radicals continued after the publishing of Huish's narrative, and the attempt to unite the Particular Baptists and Fifth 
Monarchists at Dorchester. When Richard Cromwell was forced to dissolve his parliament on 22 April 1659, the army took power, and he eventually resigned on 25 May. By this time, the Rump Parliament, who had been recalled by the army on 7 May, had already smashed Cromwell's protectoral seal, unofficially ending his reign. News of the establishment of a new parliament had reached the Loughwood congregation by 4 June and they record on this day:

That the $14^{\text {th }}$ of this instant be sett a part as a day of solemn thanksgivinge to god for his late Publique Blessinge in changinge the Government and stre[...] of Affaires in the Nation and also that prayer be then made that the Lord would blesse the powers in beinge. All Accordinge to a printed paper sent the Church from some friends in London invitinge the church thereunto. ${ }^{60}$

Such news was important enough to warrant a day of praise and thanksgiving from the community of saints, in London, Loughwood, and elsewhere. Members of the church continued to urge reform in the government. In September 1659, more than a year after publishing The Captive, John Vernon and William Allen signed the broadside plea, An Essay Toward Settlement, along with John Owen, James Hitt, and Henry Parsons, all brethren of the church at Loughwood, and leading Baptist and Fifth Monarchist adherents Hugh Courtney, Henry Danvers, Henry Jessey, and Vavasor Powell (among others). Here, the signatories prayed that there be no 'King', 'chiefe Magistrate', or 'House of Lords', as the 'late single Person (in professed pursuit of Reformation)' was 'of an haughty and abusive spirit'. They also asked for liberty of conscience: that all men might be judged by the laws set down in scripture, by a group of god-fearing men. ${ }^{61}$ Over the succeeding months, it became clear that neither the army nor the Rump Parliament were fit, or popular, enough to rule and maintain 
law and order, and the monarchy was eventually restored. All hope of religious toleration was lost, and an order for Allen's imprisonment was issued in April 1661. He was lodged in the Gatehouse until 19 June when his and Vernon's release was ordered, 'giving security of $£ 1000$ to leave the kingdom within fifteen days'.62 Neither man seems to have left the country, as Vernon later published a narrative detailing the Life, and Latter-End especially, of Caleb Vernon, his youngest son, who died on 29 November 1665. It is also evident from the narrative that, aptly enough, Vernon had become a physician. ${ }^{63}$

Regardless of what was to happen afterwards, Huish’s narrative would seem to have rallied the saints and made them a more united group or congregation. Whereas 'many Physitians' had tried to cure the saints' 'sickness' and their 'wound' (b3), referring to the literal or figurative captivity and sickness of believers like Huish, they were 'false refuges' and the saints had to try to mend the wounds themselves by following her example. Believers are asked not to be like Vernon, who recognised that he had failed in his commitment to Huish's plight, and that he was preoccupied only with ridding himself of her:

Even we that were nearest related also, left off our hope for this poor soul[.] Yea, how have I, to my shame, that had the charge of her, failed most herein! I must say indeed, to my abasement, the weights and fear of her untimely end; the cares of keeping her from any Instrument to accomplish it; [...] Alas, Pained now at no more in my own mind, then to get her safe again delivered into her dear Parents hands, that my face might not be covered with shame, according to my fear of her untimely end, at such distance from them [...] alas, she almost fell out of my memory, and was seldom in my Prayer; the Lord grant me the mercy of her earnest supplications. (a4r-v) 
Vernon berates himself for neglecting to pray for his sister-in-law and being too concerned with keeping her from any 'instrument' to harm herself. He, being the husband of the eldest Huish sister, Anne, was responsible for her well being. It was his face that would be 'covered with shame' had she accomplished the deed, and no doubt he was relieved when he delivered her back safely to her parents in Devon. Only later did Vernon realise the significance of her ordeal, the importance of her cure by conversion, and her decision to be baptised: they were all part of a divine battle between God and Satan, of which the human heart was the battleground. She became an allegory for 'the afflicted, deserted, unbelieving, divided, and thereby liable to be destroyed people’ (b3) by paradoxically opening herself up so that all might observe the spiritual battle. This made the uncontrollable somehow controllable, and the incurable, curable. Believers could see and analyse their problems, and learn how to solve or cure them by examining their 'body' of evidence. Huish became, for the Baptists and Fifth Monarchists, a memorial of God's blessings and favour, and a sign of hope for the days ahead. 


\section{$\underline{\text { Notes }}$}

I would like to express my thanks to the Arts \& Humanities Research Council who have funded this research, and to audiences both at the Durham Centre for Seventeenth-Century Studies, Twelfth International Conference, July 2009, and the Sixth International John Bunyan Society Conference, July 2010 for their questions on aspects of this article. My thanks also go to Elaine Hobby, Oliver Tearle, and the anonymous reader of The Seventeenth Century for correcting this article in its various stages.

1 William Allen, 'To the Christian Reader', in Deborah Huish and others, The Captive Taken from the Strong (London, Livewell Chapman, 1658), A2r-v. All subsequent quotations are taken from this edition. Page numbers will follow in brackets.

2 See Jonathan Sawday, The Body Emblazoned: Dissection and the Human Body in Renaissance Culture (London and New York, Routledge, 1996), pp. 41-3; A. Rupert Hall, The Revolution in Science, 1500-1750 (London, Longman, 1983), pp. 39-53.

3 Sawday, The Body Emblazoned, p. 232, citing Charles Webster, Great Instauration: Science, Medicine, and Reform 1626-1660 (London, Duckworth, 1975), pp. 66-7.

4 Indeed, modern divisions between physical and spiritual matters would not have made sense to an early-modern readership who regarded physical illness as inextricable from spiritual maladies.

5 Sawday, The Body Emblazoned, p. 3.

6 Neil Keeble, The Literary Culture of Nonconformity in Later Seventeenth-Century England (Leicester, Leicester University Press, 1987), p. 252.

7 Catharine Gray, Women Writers and Public Debate in Seventeenth-Century Britain (Basingstoke, Palgrave Macmillan, 2007), pp. 98-103. Wight's words were also transcribed and published; however, her sickness (whether spiritual and physical) appears to have been more serious than Huish's. Like Huish she experienced severe spiritual angst, refused food, 
and tried to take her own life. See The Exceeding Riches of Grace Advanced by the Spirit of Grace, in an Empty Nothing Creature, viz. Mris Sarah Wight (London, Printed by Matthew Simmons for Henry Overton and Hannah Allen, 1647). Hannah Allen subsequently married Livewell Chapman, the publisher of Huish's text. See Leona Rostenberg, 'Sectarianism \& Revolt: Livewell Chapman, Publisher to the Fifth Monarchy', in Literary, Political, Scientific, Religious, and Legal Publishing, Printing and Bookselling in England, 1551-1700: Twelve Studies (New York, Burt Franklin, 1965), pp. 203-36; Maureen Bell, 'Hannah Allen and the Development of a Puritan Publishing Business, 1646-51', Publishing History, 26 (1989), 5-66.

8 See P. H. Hardacre, 'William Allen, Cromwellian Agitator and Fanatic', Baptist Quarterly, 19 (1962), 292-308; Henry Wheeler-Robinson, ‘A Baptist Soldier - William Allen’, Baptist Quarterly, 3 (1927), 237-40.

9 Psalms 22:17 'I may tell all my bones: they look and stare at me’.

10 'Meat' in this spelling refers to the foodstuff she requires for sustenance. Bearing in mind that the experience was transcribed, it is possible that the adjective 'meet', meaning 'fitting', 'becoming', or 'proper', might also have been meant.

11 William Kiffin, Thomas Patient, and others, The Confession of Faith, of those Churches which are Commonly (though Falsly) Called Anabaptists (London, Printed by Matthew Simmons, 1644), C2.

12 Ibid., C2.

13 Anne Dunan-Page, John Bunyan, 'The Pilgrim's Progress', and the Extremes of the Baptist Mind (Oxford, Peter Lang, 2006), p. 81.

14 Richard Baxter, Plain Scripture Proof of Infants Church Membership and Baptism (London, For Robert White, 1651), p. 134. 
15 Thomas Edwards, The First and Second Part of Gangraena (London, Printed by T. R. and E. M., 1646), pp. 58, 121.

16 In published sensationalist pamphlets the offspring produced by sectaries (or indeed any objects of public derision) were usually presented as monstrous or ill-formed. These monstrous births were said to be the result of God's displeasure with the parents. Edwards's Gangraena series uses the extended metaphor of a gangrenous 'disease' attacking the 'body' of the nation as a representation of how the sectaries' heretical beliefs were infecting the country at an uncontrollable (and incurable) rate.

17 Daniel Featley, The Dippers Dipt. Or, the Anabaptists Duck'd and Plung'd Over Head and Eares (London, For Nicholas Bourne, 1645), p. 36.

18 Ibid., p. 203.

19 Edwards, The First and Second Part of Gangraena, p. 105.

20 Kiffin, The Confession of Faith, C2.

21 My thanks to the Devon Record Office for allowing me to view the records of the congregation at Loughwood in the parish of Dalwood, East Devon: Devon Record Office, Exeter (hereafter DRO), 3700D-O/M.1, Proceedings Book of Meetings in East Devon, Chiefly at Loughwood, vol. 1, 1653-1795. John B. Whitely explains that the condition of the manuscripts is due to their being stored in a barrel, exposed to the damp, before being taken to pieces and being put back together in the wrong order. It is not known how the congregation was founded, or by whom, but the first items recorded in the book are from 14 March 1654. The church building still survives today and has been restored by the National Trust for visitors. They assert that the building was established on what was then the county boundary between Dorset and Devon to allow attendees or preachers an escape to a different county's jurisdiction. For more about the church records, see William T. Whitley, 
‘Loughwood and Honiton', Transactions of the Baptist Historical Society, 4 (1914-15), 12944; John B. Whiteley, 'Loughwood Baptists in the Seventeenth Century', Baptist Quarterly, 31 (1985), 148-58.

22 DRO 3700D-O/M.1, p. 4. The 'brethren approved’ were John Owen, James Hitt, Thomas Payne, John Vernon, William Allen, and Robert Doyley. Thomas Parsons was one of the 'brethren nominated by the Church to sacrifice their gifts by way of tryall'. The hand suggests that this list was added in after the lists of members were compiled, and matches the hand that records events from 1657 onwards, the same year Allen, John and Anne Vernon, and Deborah Huish returned from Ireland. Robert Doyley was the author of the other preface to Huish's work. Owen and Doyley were also members of the army in Ireland with Allen and Vernon. For Owen see Toby Christopher Barnard, Cromwellian Ireland: English Government and Reform in Ireland 1649-1660 (London, Oxford University Press, 1975), p. 96. For Doyley see 'H. Cromwell, major general of the army in Ireland, to secretary Thurloe, 3 December 1656', in A Collection of the State Papers of John Thurloe, ed. by Thomas Birch, 7 vols. (London, Printed for the executor of the late Mr. Fletcher Gyles; Thomas Woodward; and Charles Davis, 1742), 5: p. 670.

23 Although Allen was certainly the transcriber and 'instrument' of Huish's textual 'enlargement', he was also her 'enlarger' in the sense that he was an instrument of her release from confinement and bondage.

24 See also, Anne Venn, A Wise Virgins Lamp Burning (London, Printed for E. Cole, 1658). Venn's experiences were in many ways similar to Huish's, as she too was a 'virgin' in legal terms. She also talks of assaults from Satan 'the great adversary of thy soul' (B1), and how she struggled to overcome such opposition. It is surely no coincidence that both women, who came from similarly prosperous families and who were unmarried, experienced deep, 
debilitating melancholy. It should be noted that women of the gentry were more likely to be solitary and idle, the two most dangerous occupations for those prone to melancholy, according to Robert Burton. See Burton, The Anatomy of Melancholy, ed. by Thomas Faulkner, Nicolas Kiessling, and Rhonda Blair, 3 vols. (Oxford, Clarendon, 1994), 3: p. 445. 25 My sincere thanks go to Mrs Stella Huyshe-Shires for allowing me access to her family’s home, which is only occasionally opened to the public. The outward appearance of the house at Sand has changed very little since Deborah's grandfather Rowland Huish extended the building in 1594. According to both John Burke and William Henry Hamilton Rogers, Deborah’s father, James Huish, 'engaged most actively in support of the Royal cause in the Rebellion making great sacrifices of his private fortune The estates he had inherited from his wealthy and industrious grandfather, were, some sold, and on the remainder a fine was imposed of the tenth, viz. £283. By the royalist composition papers it appears he took up arms against Parliament; laid them down in 1643, and compounded in 1646. In 1660 he received the appointment of captain in the militia of foot, raised in East Devon by the Duke of Albermarle'. See Burke, A Genealogical and Heraldic History of the Landed Gentry; Or Commoners of Great Britain and Ireland, vol. 4 (London, Henry Colburn, 1838), p. 414; Hamilton Rogers, Huyshe of Somerset and Devon: A Pedigree ed. with Notes and Illustrations (Taunton, Athenaeum Press, 1897), p. 35. If this evidence is reliable, James Huish's allowing his two eldest daughters to marry parliamentarian, Baptist army officers becomes quite remarkable. It is perhaps testament to the fluidity of political and religious affiliations in this period.

26 Huish et al, The Captive, A8v-a1, B8v-C, C2, C4; Wheeler-Robinson, 'A Baptist Soldier William Allen’, 237; Gray, p. 98. Allen was not married to an Elizabeth Huish as Stephen Wright suggests in The Early English Baptists, 1603-1649 (Woodbridge, Boydell Press, 
2006), p. 190. (In this he follows Hardacre, 'William Allen, Cromwellian Agitator and Fanatic', 299.) Wright refers to 'Elizabeth, wife of Lieut-Col. Allen' mentioned in the Calendar of State Papers Domestic, ed. by Mary Anne Everett Green (London: Longman, 1875-86), 22 March 1651, p. 554.

27 Deborah’s parents, James Huish (bap. 2 May 1604, bur. 26 May 1681) and Deborah Reynell (bap. 13 August 1621, bur. 15 June 1687), had eleven recorded children. These were, from eldest to youngest, Anne (bap. 9 May 1625, m. first to John Vernon, bur. date unknown), Mary (bap. 1 March 1626, m. William Allen, died in Dublin c. 19 December 1655), Deborah, James (bap. 15 July 1630), Rebecca (bap. 20 January 1632), John (bap. 26 February 1634/5), Rowland (bap. 21 September 1636, bur. 28 November 1638), Richard (bap. 29 November 1638), Sarah (bap. 1640), Jael (bap. 24 December 1642), and Tryphoena (bap. 5 February 1645/6). See Burke, pp. 414-15; Hamilton Rogers, pp. 35-6.

28 DRO 3700D-O/M.1. Deborah’s name appears on p. 2 and 6 under the list of members for the Sidbury area. William Allen is listed as a member of the Dalwood area, on p. 5, below the names of ' $\mathrm{B}^{\mathrm{r}}$ and $\mathrm{S}^{\mathrm{tr}}$ Vernon'. Deborah's sister Mary had died before their return from Ireland: Thomas Patient, Baptist minister in Dublin, preached her funeral sermon recorded in 'H.Cromwell to secretary Thurloe, 19 December 1655', in Papers of John Thurloe, 4: pp. 327-8. A written afterthought appears in the records beside the names of William Allen and Robert Doyley (it is not clear which the note refers to). It reads: 'Marryed $14^{\text {th }} \cdot 4 /$ mo 1659 Mrs Ann Langdon of Tragassaw in Cornwall'. This is a reference to a relation of Captain Francis Langden, who sat in the Barebones Parliament for Cornwall and lived at Tregasow, near Truro. Langden attended Anna Trapnel's bedside where she gave the prophecies published in The Cry of a Stone (London, 1654), A1v. 
29 Bernard S. Capp, The Fifth Monarchy Men: A Study in Seventeenth-Century English Millenarianism (London, Faber \& Faber, 1972), p. 143.

30 Anna Trapnel, Untitled folio in the Bodleian Library (N. pub., 1658/9), p. 273. Here, the 'King' is God, and not the late Charles I, although there is an implication that Cromwell has been generally treacherous in his usurpation of power.

31 J. F. McGregor, 'The Baptists: Fount of All Heresy', in McGregor and Barry Reay (eds), Radical Religion in the English Revolution (Oxford, Clarendon, 1984), p. 53.

32 'Sir John Cooke \&c. to Sir John Copleston, 15 May 1658', Papers of John Thurloe, 7: p. 139.

33 'Concerning Adjutant Allen, 7 February 1654[5]', Papers of John Thurloe, 3: p. 140. A 'Mr Reynell', a 'kinsman of his wife's', is mentioned as travelling with Allen. James Huish, Deborah's father, was married to Deborah Reynell.

34 Ibid., p. 140.

35 ‘From Adjutant Allen, 7 February 1654[5]’, Papers of John Thurloe, 3: p. 140. 36 Ibid., p. 140.

37 Capp, The Fifth Monarchy Men, p. 58.

38 A Declaration of Several of the Churches of Christ and Godly People [...] Concerning the Kingly Interest of Christ (London, Livewell Chapman, [2 September] 1654), B1.

39 Allen and Vernon attended a Baptist Association Meeting in Dorchester after they had published Huish's text. On 12-15 May 1658 three hundred persons were observed by Thurloe's spies, all sharing news in epistles from each of the Baptist churches represented: 'all of them much complained of the bonds and suffereings of the saints; some calling itt the time of Syon’s affliction’ ('Sir John Cooke \&c. to Sir John Copleston, 15 May 1658’, Papers of John Thurloe, 7: p. 139). During this time, Allen and Vernon gathered a private meeting 
trying to persuade influential Baptists (including William Kiffin) to join the Fifth Monarchists.

40 Capp, The Fifth Monarchy Men, p. 119, referring to Charles Harding Firth, The Last Years of the Protectorate, 1656-58, 2 vols. (London, Longmans, 1909), 1: pp. 128-200.

41 John Rogers, Ohel or Beth-shemesh A Tabernacle for the Sun (London, Printed for R.I. and G. and H. Eversden, 1653), p. 301. The letter Allen and Vernon carried, dated 14 January 1651[2], encouraged the Baptist members to secede by announcing that their Waterford church took 'offence at [their] so walking' (p. 302), and made it clear, using scripture, that they were not to mix with those of different religious opinions. Rogers, although a fellow millenarian, was an Independent and vindicated his congregation's beliefs by disproving the Baptists’ scriptural arguments (he did not agree with being re-baptised), but all to no avail. The members seceded, and Rogers returned, seemingly disheartened, to England. He reflected afterwards that Allen and Vernon 'did much mischief in the body, and made a sore rent at first from us by some whose judgement were blinded' (p. 301). See also Crawford Gribben, God's Irishmen: Theological Debates in Cromwellian Ireland (New York, Oxford University Press, 2007); Barnard, Cromwellian Ireland, pp. 90-108.

42 Barrington Raymond White, (ed.), 'The Irish Correspondence of 1653', in Association Records of the Particular Baptists of England, Wales, and Ireland to 1660, 3 vols. (London, Baptist Historical Society, 1971-4), 2: p. 114. It was signed by, among others, Christopher Blackwood, and Thomas Patient.

43 Ibid., pp. 112-13. The Loughwood congregation's records have a reference to holding a day of humiliation on behalf of their Irish brethren. On 14 March 1654 the church wrote: 'Findinge much deadness uppon the spirits of the members in generall and much unsutablenesse appearing in our Carriages to the rich grace of god manifested to us in his 
severall dealings with us, and having many weighty causes laid before us by our Brethren of Ireland all calling upon us for godly sorrow and humiliation.' (DRO 3700D-O/M.1, p. 7) 44 Gray, Women Writers and Public Debate, p. 101.

45 Thomas Heywood, Loves Mistress: Or, the Queenes Masque (London, John Raworth, 1640[1661]), E2.

46 Trapnel, Untitled folio in the Bodleian, p. 210.

47 A Declaration of Several of the Churches, B3v.

48 The Publick Intelligencer, 24-31 December 1655, 13, 78:E.491[10], pp. 193-4.

49 Capp, The Fifth Monarchy Men, pp. 107-8.

50 Michael MacDonald, Mystical Bedlam: Madness, Anxiety, and Healing in SeventeenthCentury England (Cambridge, Cambridge University, 1981), p. 167.

51 Hannah Allen, A Narrative of God's Gracious Dealings with that Choice Christian Mrs Hannah Allen (London, Printed by John Wallis, 1683), p. 8.

52 Owen Watkins, The Puritan Experience: Studies in Spiritual Autobiography (London, Routledge and Kegan Paul, 1972), p. 208.

53 John Bunyan, The Holy War (London, Printed for Dorman Newman, 1682), A2.

54 Gray, Women Writers and Public Debate, p. 100.

55 MacDonald, Mystical Bedlam, p. 186.

56 Burton, The Anatomy, 3: p. 433.

57 Ibid., 3: p. 425.

58 A number of testifiers give accounts of the temptations of the devil to make away with themselves. Vavasor Powell includes an account of D. M. who was tempted by Satan to drown herself in a pond near Leeds. See Powell, Spirituall Experiences, of Sundry Beleevers (London, Printed for Robert Ibbitson, 1651/2), pp. 33-6. Hannah Allen’s testimony tells 
similarly of the Devil's temptation to give way to suicidal tendencies. See Hannah Allen, $A$ Narrative, p. 44.

59 Henry Pinnel, Philosophy Reformed and Improved in Four Profound Tracts (London, 1657), p. 43, cited in Sawday, The Body Emblazoned, p. 233.

60 DRO 3700D-O/M.1, p. 34.

61 An Essay Toward Settlement Upon a Sure Foundation (London, Printed for Giles Calvert, [19 September] 1659).

62 Hardacre, ‘William Allen’, p. 305.

63 John Vernon, The Compleat Scholler; A Relation of the Life, and Latter-End Especially, of Caleb Vernon (London, For the Author, 1666). John and Anne Vernon seem to have five children from those mentioned: John, Caleb (b. 1653 in Dublin and d. 29 November 1665), Mary (b. 1657, Sand Sidmouth), Nancy (b. 1660/1), and Betty. Anne’s lying-in before the birth of Mary (named after her recently deceased sister) is recorded by Huish: The Captive, C2. A letter from a R.D. is mentioned (possibly Robert Doyley) which mentions a 'cousin Deborah', but most likely refers to a child of William and Mary Allen's, as Deborah had died in 1661. Anne’s younger brother James named his first daughter Deborah, but she was not born until 1685.

\section{Address for Correspondence}

Dr Rachel Adcock, Department of English and Drama, Loughborough University, Leicestershire LE11 3TU, email: R.C.Adcock@lboro.ac.uk

\section{$\underline{\text { LAST }}$}

